\title{
Helsinki: A software sorted city? A case study of the geodemographics industry in Finland
}

\author{
VILLE TAKALA
}

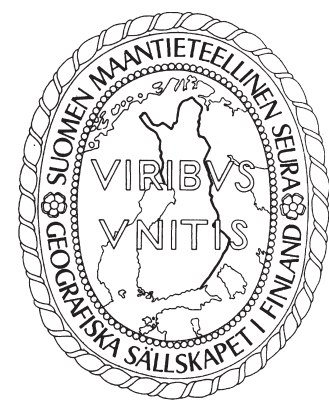

Takala, Ville (2014). Helsinki: A software sorted city? A case study of the geodemographics industry in Finland. Fennia 192: 2, pp. 140-153. ISSN 1798-5617.

\begin{abstract}
Over the past ten years or so, social scientists have started to pay an increasing amount of interest in the role that computer software is playing in contemporary urban environments. So far, approaches that treat information technologies as increasingly constitutive of the social world have been missing in Finnish Sociology. On the other hand, after an initial period of activity around sociological analysis of various information technologies in the UK, there has been something of a lull. This paper takes one example of influential information technology, geodemographic neighbourhood segmentation software, and analyses it in the context of Helsinki, the capital of Finland. The analysis consists of three parts. First, based on existing literature, a brief history of Helsinki is provided. Secondly, commercial geodemographics of Helsinki are analysed in detail from the perspective of Finnish Urban Sociology. The analysis pays specific attention to the problems that arise when a classification scheme developed in the UK is translated in to the historical and cultural context of a Nordic welfare State. Finally, the paper looks at the theoretical debates around geodemographics, and considers directions for future research in the area. After all, the inundation of digital data in our culture has not only been seen as a new subject of inquiry for social science, but as an intensifying methodological challenge for the entire discipline.
\end{abstract}

Keywords: Geodemographics, Helsinki Metropolitan Area, Social geography, Commercial data, GIS, Research methodology

Ville Takala, Department of Sociology, Goldsmiths, University of London, New Cross, London, SE16 6NW, E-mail: v.takala@gold.ac.uk

\section{Introduction}

According to the grand old man of Finnish Sociology, Erik Allardt (Allardt et al. 1992: 21), a distinctive feature of Finnish society is the fact that many international social developments have taken place relatively late in comparison to the rest of Europe. However, once the developments have started, they have often been abrupt. The capital of Finland, Helsinki, is a city on the verge of becoming a major Northern European metropolis, thus making it an ideal subject for an analysis of how "software sorting technologies" are affecting the development of a city.

Over the past ten years or so, social scientists have started to pay an increasing amount of interest in the role that computer software and code are having on nearly all aspects of contemporary social life (see for example Amin \& Thrift 2002; Thrift \& French 2002; Graham 2005; Burrows \& Gane 2006; Beer \& Burrows 2007; Beer 2009; Kitchin \& Dodge 2011; Gillespie 2013). According to Kitchin and Dodge (2011) just as steam was at the start of the industrial age, software is today the lifeblood of the information society. Software is making a difference to how social and economic life takes place by influencing fields such as domestic chores, work, shopping, traveling, communicating, governing and play. For urban research, the most important aspect of software is that it has started to produce space (Thrift \& French 2002). 
In this article I will look at a particular piece of software, commercial geodemographics, which have been thoroughly analyzed in the context of British sociology, but of which similar analyses have so far been missing in Finland. Commercial geographical information systems are perhaps the most important example of the new information technologies that increasingly shape social and geographical inequality in our cities (Graham 2005). Neighbourhoods, and thereby the people living in them, are classified and labelled by commercially available software such as Acorn and Mosaic. In short, geodemographic classifications are built by combining Census data with a large number of external data mostly derived from commercial sources (Harris et al. 2005). After the initial analysis, different neighbourhoods are classified and labelled via the production of a narrative that best describes the "sort of people" who reside in the different neighbourhoods. In the UK, for example, there are currently approximately 1.7 million postcodes covering, on average, about 14 houses each, and every postcode is allocated to a particular category by Acorn \& Mosaic (Burrows \& Gane 2006).

Commercial geodemographics as we know them today originated from the world of post-war academia. In the US, Jonathan Robbins, a former faculty member of the Department of Sociology at New York University, applied his knowledge of sociology, demography and statistics to the development of a system for targeting housing grants to cities with a history of rioting. PRIZM, a software that provided 4040 mutually exclusive and exhaustive lifestyle clusters for all 36,000 USA ZIP codes, grew out of this work. At about the same time in the UK, a social scientist named Richard Webber was developing a similar software that would identify clusters of neighbourhoods for which different types of urban deprivation interventions were appropriate. Out of this grew the first UK-based geodemographic classification system. Both Webber and Robbins left the domain of academia and social policy to develop their systems in to more commercial directions. Webber himself has observed how ironic it is that a tool originally designed to distinguish between poor areas came to be used as a tool for differentiating between areas where rich people reside (Burrows \& Gane 2006: 794-795).

Today, both public and private sector institutions are using the data produced by companies such as Experian (producer of the Mosaic classification system) to make highly informed decisions on where to locate their services. The Mosaic alone, claims to be used by over 10,000 different organizations (ibid.). In a world where residential location can increasingly be seen to come to define "social class" (Parker et al. 2007), and vice versa, we need to take a critical look at the institutions which not only have the power to classify and label places, but also the people situated within those places. This power increasingly lies within commercial institutions such as Experian rather than nation states or even other systems of local governance (Burrows \& Gane 2006).

In this article I will look at commercial geodemographic maps built of the capital of Finland, Helsinki. Since the 1990s, Geographic Information Systems (GIS) have been an important tool for academic social researchers in Finland. Therefore, it is perhaps surprising that in a similar fashion to the UK (Burrows \& Gane 2006), also in Finland there has been close to no ongoing interaction between academic and commercial geographers. Commercial market researchers, who do not necessarily consider themselves as sociologists, are working on technologies that have clear sociological significance and value. In this context it is important that social scientists start to develop an understanding of how the different classifications are constructed (Uprichard et al. 2009), by whose agency they are constructed, and for what original purposes (Parker 2011). By introducing and critiquing geodemographic maps of Helsinki, this article aims to provide a starting point for further analysis of these systems in a Nordic context.

The article consists of four parts. In the first part I will contextualize Helsinki by looking at its history and current social developments. This will provide us with a framework from which we can understand contemporary geodemographic classifications of the city and its different neighbourhoods. In the second part of the article I will provide an overview of geodemographics in Finland. Once this is done, I will analyse the geodemographic maps of the Helsinki metropolitan area in detail. Perhaps the biggest and most heatedly debated question in Finnish Urban Studies of the last decade has been the question of whether the Helsinki region has recently been witnessing a historically new form of neighbourhood differentiation (Vaattovaara \& Kortteinen 
2003). I will relate the analysis of the maps to this discussion, and consider whether a sociological evaluation of what is essentially commercial software will help us to understand the social geography of Helsinki.

In addition to the UK and Finland, commercial neighbourhood classifications have been built of countries such as France, Germany, the Netherlands, Spain, Belgium, Denmark, Greece, Ireland, Italy, Norway, Sweden, Canada, the USA, Australia, New Zealand, China, Japan, Brazil and Peru (Harris et al. 2005). In the context of this growing global reach, it is important to consider whether a technique developed in one country can be successfully used to map the social structures of other countries. I will therefore compare the Mosaic Finland to the original British equivalent, and consider why, on many occasions, the categories and classifications that work so well in the UK simply do not hold the same explanatory power in the context of a Nordic Welfare State.

The final part of the article considers the theoretical implications that systems such as commercial geodemographics might have on contemporary social sciences. I will consider these questions in relation to a recent debate about the crisis of empirical sociological research methods in an age of increasing amounts of digital transactional data. In order for us to understand the social geography of a city however, we must first take a closer look at its history.

\section{A brief history of the Helsinki metropolitan area}

Research on urban segregation in Finland started in the 20th century, when for example Heikki Waris (1932) studied the birth and development of the industrial districts of Helsinki. From the early days of industrialization in the late nineteenth century, and all the way into the post war years, Helsinki was clearly divided between workers' districts and bourgeois neighbourhoods (ibid.). After the Second World War, the Helsinki region was strongly affected by a policy of social mixing in Finnish urban planning. Together with an aggressive redistribution of wealth by the welfare state system, the policy of social mixing helped to produce an exceptionally balanced city in terms of its social and geographical equality. In the early nineties, regional differences in Helsinki were very small in comparison to other European cities. Also largely due to the policy of social mixing, even the richest parts of the city included its share of social housing. Concentrations of relative deprivation existed only in small "pockets of poverty" within individual houses or blocks scattered around the city (Vaattovaara 1998).

A deep recession in the early 1990s posed a significant challenge to the city's socio-economic structure. The rise of the information industries, that essentially lifted Finland out of the depression, led to a structural shift in the demand for labour and as a result, the new economy lifted some areas out of the depression faster than others. Certain neighbourhoods, of which many were located in the eastern parts of the city, never truly recovered from the depression of the nineties. During this time period Helsinki's city structure started to develop in a way that to a large extent resembles other European cities: The inner city retained its vitality, while the effects of deindustrialization were felt hardest in the suburbs. At the same time semi-detached housing started to spread and form a ring at the outskirts of the region (Vaattovaara \& Kortteinen 2003).

Finland has often been celebrated as a model state in the information age (see for example Castells \& Himanen 2002). Indeed, during the last few decades Finland has been successful in transforming in to a globally integrated ICT-driven economy while at the same time maintaining a strong welfare state. The Helsinki region has been at the forefront of this development, and today thirty per cent of the entire Finnish GDP is produced in the Helsinki Metropolitan Area (Cantell \& Jaakola 2012). In 2009, thirty percent of the population in Helsinki was working in fields defined as knowledge and creative industries (Kepsu \& Vaattovaara 2008). The popular economic geographer Richard Florida has regularly placed Finland among the most economically competitive countries in the world (see for example Florida 2012).

However, more recently there have been signs of a growing tension between the egalitarianism of the welfare state and the competitiveness of the information economy. According to Vaattovaara et al. (2011) the two basic postulations of the Finnish Welfare State, low income inequality and full employment, have been lost as a consequence of developments that have occurred during the last two decades. Following what seems 
to be an international trend, the richest one percent in Finland increased its incomes by 122 percent from 1990 to 2001, whereas the comparable growth rate was only 1 percent for the first decile and 7 percent for the second decile (Uusitalo 1997: 3). At the same time, the growth of relative poverty has been the fastest in all OECD countries (Ritakallio 2010). The growth of poverty has not been linked with deprivation in consumption, but with a growth in income differentials (ibid.).

Another change in the social structure of Helsinki has been the emergence of structural unemployment and low employment rates. Before the 1990s, there were in practice almost no long term unemployed in Helsinki. By contrast, in 2010, the unemployment rate was 8.6 percent of which 19 percent was long term unemployment (Vaattovaara et al. 2011: 8). This phenomenon has also started to cluster within the city, as nearly half of the people in their working age - excluding students - in Helsinki's social rental housing do not work but live on social benefits of some kind (ibid.: 9). There have also been some signs of ethnic clustering: approximately 60 percent of those foreign-speaking residents who lived in some kind of state-subsidised housing in 2003 lived in buildings where the share of foreign-speaking population exceeded 20 percent. In Sweden, this threshold has seemed to trigger the outflow of natives (Vilkama 2006).

All in all, recent research shows that spatial divisions created by the social and economic developments of the 1990s are still very much present today. The Helsinki region has recently been witnessing a slight growth in socio-economic and ethnic differences, particularly between the richest and poorest neighbourhoods. Low income, low education levels, higher-than-average unemployment, and various health problems are largely clustering in the same neighbourhoods. However, by international standards, neighbourhood differentiation in Helsinki is still modest and so far there have not been signs of severe urban segregation (Vilkama 2012). Nevertheless, some of the developments that are currently taking place within the region are worrying.

In August 2012, Helsinki's population reached 600,000 , and by 2030 the population figure is expected to be at almost 680,000 (Laakso \& Vuori 2012). By then, the Helsinki region (consisting of municipalities Helsinki, Espoo and Vantaa) will have grown into an area of 1.6 million residents. The expected population growth is primarily due to in-migration from the rest of the country, foreign migration and natural population growth. In contrast to the population as a whole, largest age groups in Helsinki are not the post-war baby boomers, but the 20-30-year-olds (Cantell \& Jaakola 2012). Helsinki's importance and influence will undoubtedly only grow in the years to come. After providing an overview of the history and recent developments in Helsinki, I will now look at the geodemographics industry in Finland in detail.

\section{Geodemographics in Finland}

In this section of the article I will introduce Mosaic Finland by examining how the classification system typifies households in two distinct parts of Helsinki. This will work to demonstrate what type of information is regarded as important by consumer segmentation software such as Mosaic Finland.

On the contrary to the UK version, Mosaic Finland does not use postcodes as its main unit. This is due to the fact that the Finnish 5-digit postcode is a large geographic unit (with anything between 30 and 14,000 households) and is therefore not of much use for neighbourhood segmentation. Instead, the latest version of Mosaic Finland, released on 21st February 2012, splits the country up into 250 by 250 meter grids and categorizes each populated area into 9 main- and 33 sub-groups. Each of these so called Mosaic Units includes an average of 7 houses (Experian 2011). Finland is a sparsely populated country, and no less than 327888 areas are marked as non-zero population areas (Experian Marketing Services 2011). For the time being, Mosaic Finland is only available as commercial software, but there is no reason to assume that it would not become accessible publically in Finland, following international practices (Mosaic UK was released as a free iPhone application in February 2011). Table 1 shows the Mosaic Finland groups and types released in February 2012. The group and type names as well as descriptions are available both in English and in Finnish.

As an example, let's consider how Mosaic Finland typifies two addresses in which the author has lived in during the past three years. The first address, located within the wealthier bits of the city (Taka-Töölö), belongs according to Mosaic 
Finland in the category of Big City Lights $(4.68 \%$ of all households in Finland). This category consists of two sub-categories, Central City Trend Elite $(2.88 \%)$ and Capital Career Adults (1.80\%). Central City Trend Elites are summarized as "People with a university education and a good income, living in central city areas". The overview of the group is as follows:
"The type consists mainly of adults aged 25-34 who live in central city areas either alone or as couples without children. A university degree is clearly most over-represented among educational levels. Among occupational groups stand out managers, special experts as well as office and customer service workers. Among income classes, the highest one is emphasized. The proportion of Swedish-speakers notably ex-

Table 1. Mosaic Finland Groups and Types (C Experian 2011).

\begin{tabular}{|c|c|c|c|c|c|}
\hline Group & Mosaic Group Name & $\%$ Households & Type & Mosaic Type Name & $\%$ Households \\
\hline \multirow{3}{*}{$\mathbf{A}$} & \multirow{3}{*}{ Elite } & \multirow{3}{*}{8,71} & A01 & Big Shots & 1,80 \\
\hline & & & $\mathbf{A 0 2}$ & Quite Big Shots & 3,64 \\
\hline & & & $\mathrm{A03}$ & Elite & 2,38 \\
\hline \multirow{5}{*}{$\mathbf{B}$} & \multirow{5}{*}{ House-Owner Families } & \multirow{5}{*}{15,03} & B04 & Own House Dream & 3,77 \\
\hline & & & B05 & Own House and Overalls & 4,01 \\
\hline & & & Bo6 & Common Life in a Terraced House & 3,95 \\
\hline & & & $\mathrm{BOT}$ & Terraced House, Kids \& Rock 'n' Roll & 3,28 \\
\hline & & & B08 & Toddlers and House Project & 0,01 \\
\hline \multirow{2}{*}{ C } & \multirow{2}{*}{$\begin{array}{l}\text { Responsibility with } \\
\text { Wealth }\end{array}$} & \multirow{2}{*}{7,78} & $\mathrm{CO9}$ & Business, Family and Flowerbed & 4,18 \\
\hline & & & C10 & Established White-collars & 3,61 \\
\hline \multirow{2}{*}{ D } & \multirow{2}{*}{ Big City Lights } & \multirow{2}{*}{4,68} & D11 & Central City Trend Elite & 2,88 \\
\hline & & & D12 & Capital Career Adults & 1,80 \\
\hline \multirow{5}{*}{$\mathbf{E}$} & \multirow{5}{*}{ Paperwork and Balcony } & \multirow{5}{*}{15,53} & E13 & From Flat to Office & 5,17 \\
\hline & & & E14 & Young Flat-Renters & 3,63 \\
\hline & & & E15 & Suburban Singles and DINKS & 2,10 \\
\hline & & & E16 & Student Life & 0,68 \\
\hline & & & E17 & Inner-city Small Households & 3,95 \\
\hline \multirow{4}{*}{$\mathbf{F}$} & \multirow{4}{*}{ Post-Career Life } & \multirow{4}{*}{14,76} & F18 & City Seniors & 5,82 \\
\hline & & & F19 & Pension, Local Shop and TV & 1,17 \\
\hline & & & $\mathbf{F} 20$ & Town Pensioners & 4,36 \\
\hline & & & F21 & Active Seniors & 3,41 \\
\hline \multirow{4}{*}{ G } & \multirow{4}{*}{ Life in High-Rise } & \multirow{4}{*}{14,47} & G22 & Shopping Centre and Rented Flat & 2,97 \\
\hline & & & $\mathbf{G 2 3}$ & Work, Toyota and Sport News & 5,53 \\
\hline & & & G24 & From the Country and Abroad & 2,69 \\
\hline & & & G25 & Night Shift and Nursery & 3,28 \\
\hline \multirow{3}{*}{$\mathrm{H}$} & \multirow{3}{*}{ House and Garden } & \multirow{3}{*}{11,05} & $\mathrm{H} 26$ & Small House Life & 4,20 \\
\hline & & & $\mathrm{H} 27$ & Old House and Caravan & 4,48 \\
\hline & & & $\mathrm{H} 28$ & Swedish-Speakers of the Coast & 2,37 \\
\hline \multirow{5}{*}{$\mathbf{I}$} & \multirow{5}{*}{ Countryside Folk } & \multirow{5}{*}{8,89} & 129 & Big Countryside Families & 0,12 \\
\hline & & & 130 & Plot and cabin & 1,73 \\
\hline & & & 131 & Upscale Farmers & 0,43 \\
\hline & & & 132 & Elderly in the Heartland & 3,12 \\
\hline & & & 133 & Farm and Tractor & 3,48 \\
\hline
\end{tabular}


ceeds the national average, and a mother tongue other than Finnish or Swedish is also relatively common. The home is typically quite small and rented in block of flats built in the 1950s or earlier. Also homes from 1960s are quite common. The families live especially in Helsinki, typically in central parts of it, or in Espoo. There are also many families living in other central areas of the other biggest cities" (Experian 2010).

People in this group make their daily purchases in their neighbourhood shops. S-Etukortti is identified as the most actively used customer card, and the people in the group pay more visits to Stockmann (arguably the most luxurious department store in Finland) than people in any other groups. Among media, newspapers such as Helsingin Sanomat and Hufvudstadsbladet stand out. The type watches TV relatively little, but follows news and documentaries on a regular basis. Among channels Nelonen (TV) and YLE X (Radio) stand out (ibid.).

As for home and car investments, most of the buildings occupied by this group are connected to cable TV, and home theater devices are more common than the national average. The number of sailing boats exceeds the national average, summer cottages are common, but cars are relatively few. If the household does have a car however, it is more expensive than the national average. European and American sports cars and sports utility vehicles are preferred. Over one fifth of the cars were bought new, which very clearly exceeds the national average (ibid.: 14).

One does not need much sociological sophistication to grasp that this is a fairly accurate description of the type of people who usually like to live in the inner parts of Helsinki. In fact, this habitus group is familiar to anyone who has lived in the city for more than a few years, in spite of ones familiarity with sociological theories such as those of Pierre Bourdieu's (1986) on the cultural aspects of social class.

The second former address of the author, located within that part of the city which was born as a consequence of the industrial revolution (Waris 1932), Kallio, is classified by Mosaic as Paperwork and Balcony $(15.53 \%$ of all households). This group is further divided in to five sub-categories: From Flat to Office $(5.17 \%)$, Young Flat-Renters (3.63\%), Suburban Singles and DINKs (Dual Income No Kids) (2.10\%),
Student Life $(0.68 \%)$ and Inner-city Small Households (3.95\%). The sub-groups are fairly similar in their constitution, in the sense that most are young people living in smaller flats (although pensioners are included in the first category). The biggest sub-group, From Flat to Office is summarized as "Singles and couples with an average income, living in fairly old blocks of flats". The overview of the group is as follows:

\begin{abstract}
"The households are mostly young single adults and, on the other hand, middle-aged or pensioner couples whose children have already moved away from home. There are few families with children in this type. The income rate of the families is slightly under the average, and livelihood comes most often from customer service or office work. A typical home is a smallish flat in a block of flats built in the 1960s or 70s, in a town or city milieu. The families live in big cities and in the municipalities surrounding Helsinki." (Experian 2010).
\end{abstract}

Purchases are typically made in jumbo markets or department stores and S-Etukortti is the most frequently used customer card. The group read magazines very little, but among single magazines, health magazines aimed at women, such as Hyvä Terveys, Voi Hyvin and KuntoPlus, as well as Kauppalehti among business papers stand out. The type is described as slightly more passive as a consumer group than the national average. Cars are mainly small and in the least expensive price groups, or small family cars. Among countries of manufacture France, Italy and Spain stand out (ibid.). In the next part of the article I will analyse the geodemographic maps of the Helsinki metropolitan area in detail.

\section{Geodemographic maps of the Helsinki metropolitan area}

Figures 1 and 2 illustrate how the Mosaic Finland categorises the Helsinki metropolitan area. A detailed analysis of the maps reveals that the Mosaic Finland confirms many presumptions about the socio-economic structure of the area. In particular, the classification scheme reflects many of the patters on neighbourhood differentiation that have been identified by urban researchers in Finland.

Three major themes stand out from the analysis of these maps. First, the outskirts of Helsinki, espe- 
cially in the west, are strongly characterised as being inhabited by elite groups. By examining Figure 1 we can see that most of the belt which is formed outside the city centre is categorized as group A, Elite areas. The overview of the Elite group, which is further divided to Big Shots, Quite Big Shots and Elite, is as follows:

In the whole group, there are many families with children. The most notable age groups are school children and parents in their forties. The families in this group are clearly bigger than the national average. The proportion of those in working age and with a university education is well over the national average. Among occupational groups, managers, highest officials and experts are emphasized.... A typical home is a one-family, semi-detached or terraced house, built in the 1980 s or later. Homes are notably bigger than average and mostly owner-occupied. The Elite lives in esteemed areas of residence, mostly in the biggest cities and around them... Among frequent customer programmes, Stockmann stands out most clearly. The group reads a lot, especially business, technology and youth magazines... Summer cottages are common, in type A1 the most common of all types. Big investments are made in hobbies and hobby gear as well as other purchases. (Experian 2011).

Figure 1 also shows us that other groups, such as group C (Responsibility with wealth), B (Houseowner families) and $\mathrm{H}$ (House and Garden) are included, not as consistent areas, but rather as specific ones within the wealthy belt. The elites are clearly more heavily located in the western parts of the region, specifically in the neighbouring municipality Espoo, but also eastern parts of Helsinki has its elite areas. This finding reaffirms the common assumption that many of the residents in Espoo are well off.

Second finding of the analysis is that inner city Helsinki is almost exclusively dominated by group D, Big City Lights, as can be seen clearly by examining Figure 2. The Mosaic Finland categorises this group, which consists of sub-groups Central City Trend Elite and Capital Career Adults, as following:

"A typical household consists of young adults without children, living alone or as couples. They mostly have a university-level education... This group lives in the central city areas of the biggest cities... A typical home is small flat. Daily purchases are mostly made in neighbourhood shops. Being Stockmann's frequent customer is almost self-evident in this group... High penetration of cable TV, and broadband connections is accounted for by the central city location, but in addition this group has clearly more sailing boats than the national average... The most widely read newspapers are Helsingin Sanomat and Huvudstadsbladet. Business papers are clearly read more actively than average, while among magazines housing and home magazines stand out in type D11 and single hobby magazines in type D12. On TV, the group watches mostly news and documentaries." (Experian 2011).

This description comes somewhat close to Richard Florida's $(2002,2012)$ analysis of the so called Creative Class. It seems to be the case that, according to Mosaic Finland, the central part of Helsinki is inhabited by the type of people identified by Florida as key workforce in modern information economies.

Third finding of the analysis is that the most deprived of the categories, group G, Life in HighRise, is quite strongly located in the eastern parts of the city. As a category, Group G, most strongly indicates areas with residents at the bottom of the socio-economic scale. This group (consisting of sub groups Shopping Centre and Rented Flat, Work Toyota and Sport News, Night Shift and Nursery, From the Country and Abroad) is summarized as following:

"In this group, there are single adults, couples without children and families with children. The level of schooling is low in this group, and the income of the households is small. Jobs are usually in industry. Unemployment is also more common than average, and there are clearly more payment defaults than the national average. There are rather few Swedish-speakers in this group. The most typical form of housing is a rented flat in a block of flats. This group is mostly located in suburban housing estates built in the 1970s... Among media, the group is interested in afternoon papers and gossip magazines, and they also watch TV actively... summer cottages and cars are quite few, and cars are often old and inexpensive." (Experian 2011).

By looking at the Mosaic Finland map we can see that the group is heavily represented in the eastern parts of the city, but single grids exist in other parts as well. It would not be surprising if the red dots on the map in Figure 1 would in fact represent some of the so called "pockets of poverty" that were identified by Finnish urban researchers in the late 1990s and early 2000s (Vaattovaara 
Fig. 1. Mosaic Finland groups ((A) Elite, (B) House-owner Families, (C) Responsibility with Wealth, (D) Big City Lights, (E) Paperwork and Balcony, (F) Post-Career Life, (G) Life in High-Rise, (H) House and Garden, (I) Countryside Folk \& (U) Unclassified) in Helsinki Metropolitan Area (๑ Experian 2011).

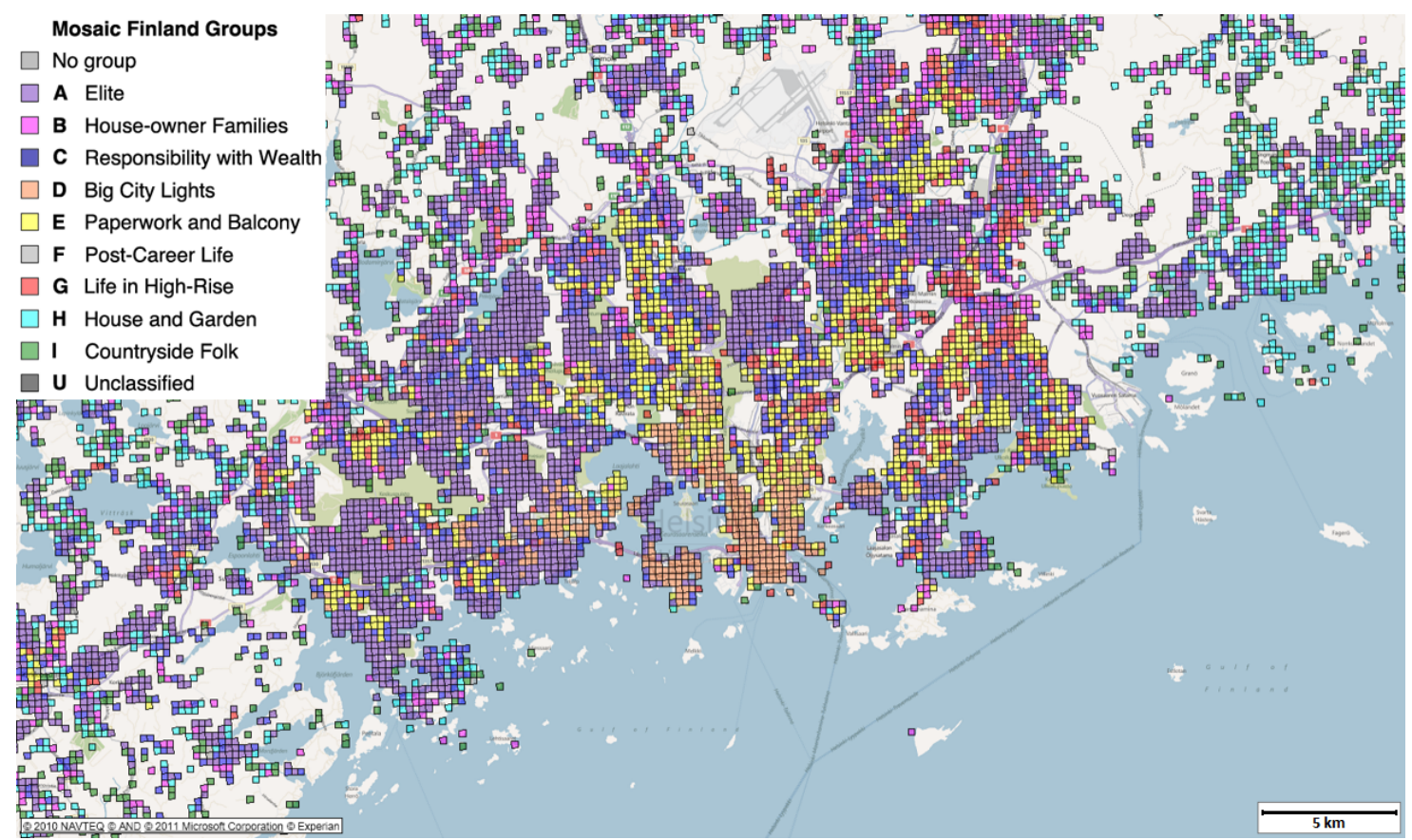

Fig 2. Mosaic Finland Helsinki map 1 (C Experian 2011).

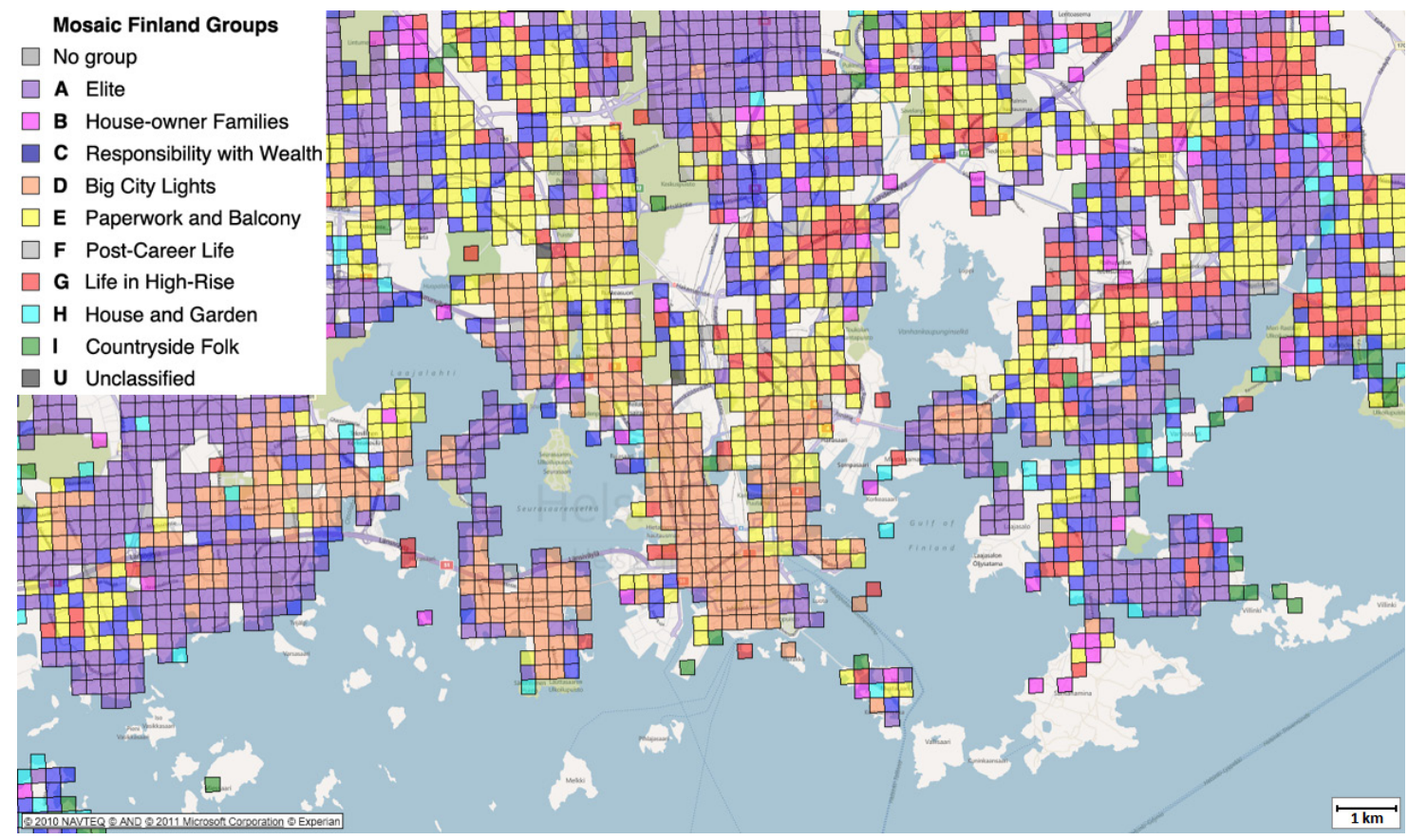


1998). This however cannot be determined, since the original pockets of poverty were made unidentifiable due to privacy concerns.

All in all, the Mosaic Finland's classification of the Helsinki metropolitan area reflects many of the patterns of neighbourhood differentiation that have been identified by Finnish urban researchers in the early 2000s and later on. It is not surprising to find that affluence is more heavily located in the western parts of the city, while relative deprivation is more prevalent in deindustrialized eastern districts. However, it is also clear that the translation of the British classification scheme to the context of Finland causes major problems with the accuracy and depth of the classifications. I will use the next section to consider the underlying causes for these methodological issues.

\section{Do geodemographics travel? How well does a classification scheme developed in the UK work in Finland?}

As noted previously, commercial neighbourhood classifications have been built of numerous countries around the world. Comparisons across nations are also possible with products such as Mosaic Global, a system that classifies 800 million consumers across 17 countries into 14 different types of residential neighbourhoods (Harris et al. 2005). In the context of the global reach and influence of these systems, it is crucially important to examine the problems that arise when a classificatory technique developed in one country is translated across different cultures and historically specific social contexts.

A detailed investigation of the Mosaic Finland reveals three major issues with the classifications and resulting maps. First, it is important to keep in mind that the original Mosaic was developed in order to identify social differentiation in a country with centuries of class divisions. Finland's historical context is rather different. The country's challenging geopolitical location between two great powers, Sweden and Russia, is reflected in many ways throughout its history. For example, compared with British, French or German educational systems, the Finnish educational system has never been very selective, but opportunities have instead since early on been provided for all social classes in all parts of the country (Mäkelä 1999). Education attendance and labour market participation of women have also been some of the highest in Europe. Simply put, as a small country next to powerful neighbours, Finland has not been able to afford to have any part of its population being left out (Chapain et al. 2010).

This historical context of being surrounded by powerful neighbours on both sides has also resulted in a rather unified national political front. Historically, the small national elites have been allied with the governmental bodies in order to work together "for the best of the common people" (ibid.: 271). Therefore, for a long time national political guidance to raise levels of education, standards of living, housing conditions and available services have been met with almost no resistance whatsoever (ibid.). From a sociological point of view, this historical background has meant that taste hierarchies have not differentiated to the same extent as in some other western countries (Mäkelä 1999).

Perhaps these are some of the reasons why it is not very informative for someone who is Finnish to read about the differences in purchasing behavior and media use between the different groups identified by the Mosaic Finland. In addition to the historical context, two contributing factors must be mentioned here. First, retail in Finland has been strongly monopolized between a few chain stores since the seventies. The most popular customer card in a specific group therefore tells very little, if anything at all about the group. Second, perhaps also due to the small size of the country, media has diverged very little. Helsingin Sanomat is by far the largest subscription newspaper in Finland, and due to its superior size, other newspapers in Finland do not really have the resources to compete with it as opinion leaders. Unlike in a country such as the UK, it is not possible to gain insights in to a person's political preferences by looking at which newspaper the person has lying on the dinner table. Same holds true for TV: Pretty much the same few channels are watched by people with different socio-economic backgrounds throughout the country. Traditionally families all over the country have gathered around the television to watch the half eight news broadcasted by the public broadcasting company, Yleisradio. This activity has on more than one occasion been identified by social scientists as the most important ceremony of nation building taking place in the small nation state (Herkman 2001).

The strong historical tradition towards egalitarianism, the small size of the country, the monopoly in retail, and the relatively speaking non-existent 
differentiation in taste hierarchies and media are factors that contribute to a situation where key words in purchasing behavior and media use seem to tell us very little about the different social groups that inhabit the city. Finland remains a small, very homogeneous nation-state with extremely low levels of income inequality in international comparison (CIA 2012). Due to these reasons, the group descriptions and indicators that 'work' so well in the UK (see for example Burrows \& Gane 2006; Parker et al. 2007; Uprichard et al. 2009) do not seem to hold the same explanatory power in the cultural context of Finland. These findings are in many ways no surprise, since it seems rather obvious that when a classificatory scheme developed in a country with a long history of class divisions is applied to a more egalitarian one, the end result is nowhere nearly as informative.

The second major issue with the Mosaic Finland is perhaps less obvious, but it is also related to the fact that the premises for the classifications are derived from the cultural context of the UK. As noted previously, the Mosaic Finland splits the country up into 250 by 250 meter grids and categorizes each populated area into 9 main- and 33 sub-groups. By doing so, it makes the assumption that the average values for these areas accurately describe the type of people living in them. Again, this assumption might hold true in the UK, where different social groups have historically been clearly segregated in to different neighbourhoods. Helsinki however, and as mentioned previously, has since the sixties been strongly affected by an aggressive policy of social mixing, whereby social housing blocks have been mixed with private housing. As a result, the housing blocks are sometimes very diverse in terms of their socio-economic composition. The size of the average housing block is by far smaller than the 250 by 250 meter grid area used by the Mosaic Finland. By categorizing these areas based on their averages, the Mosaic Finland is unable to account for the sometimes remarkable socio-economic variation within them.

This methodological issue, also known as the ecological fallacy, manifests itself in at least two ways in the Mosaic Finland's mapping of the social structure of the Helsinki metropolitan area. First, it is important to remember that since the sixties, the policy of social mixing has been most influential on one hand in inner parts of Helsinki, and on the other hand in the suburbs that were built in the 1970s. However, the ring of semi-de- tached housing at the outskirts of the region has not been influenced by this policy. By re-examining Figure 1, we can see that Mosaic Finland classifies these areas, of which many are located in Helsinki's neighbor municipality Espoo, as areas where the Finnish elites are clustered.

This conclusion is however incorrect. There are in fact about twice as many households in the highest income decile in Helsinki compared to Espoo (Kortteinen \& Vaattovaara 2011). While it is true that in Helsinki the outskirts of the region have indeed increased their relative wealth during the past few decades, it is nevertheless still the case that in general household incomes increase with proximity to the city center (Laakso \& Loikkanen 2004). These very affluent households close to the city center are often mixed together with young people with small incomes living in small rental apartments. Considering the commercial nature of the software, it is rather surprising that the Mosaic Finland is in fact not very good at identifying where wealth is actually located.

Second, the same issue also affects the Mosaic Finland's ability to identify differentiation at the lower end of the socio-economic scale. The part of the city that emerged as a consequence of the industrial revolution in Finland, Kallio, is almost exclusively categorized as group D. Big City Lights (further divided in to Central City Trend Elite and Capital Career Adults) areas. While it is true that many of the inhabitants in Kallio are highly educated youth, the Mosaic Finland seems to exclude completely the remains of the old working classes in the area. Measured by any indicator, Kallio has historically been the overwhelmingly poorest part of Helsinki. The housing stock consists mainly of small rental apartments (Helsingin kaupungin tietokeskus 2010), and the policy of social mixing has not been as influential there as elsewhere. A large part of the inhabitants in today's Kallio are students and those who became permanently unemployed during the 1990s recession. Consequently, the area still has a relatively high unemployment rate (Salorinne 2014). One can only guess that the Mosaic Finland's tendency to ignore these areas is in part due to the limited interest deprived groups offer as consumers. As well as not being very good at identifying where wealth is actually located, perhaps less surprisingly, the Mosaic Finland is also systematically ignoring some areas at the lower end of the socio-economic scale. 


\section{Discussion: Sentient cities and the crisis of empirical sociology?}

The theoretical discussions around geodemographics touch on many of the most interesting themes in contemporary social sciences. As stated previously in this article, there has recently been a growing sense of acknowledgement about the importance of analyzing code and software sociologically. It is increasingly the case that our movements through space and time produce data that is harvested and analyzed by commercial institutions. Individual consumption practices produce traces of data that are used to construct neighbourhood classifications, which in turn have an influence on where services are located. Here we can identify a possible loop whereby commercial neighbourhood classifications have the potential of accelerating existing processes of neighbourhood differentiation.

For example, a huge volume of customer information is now harvestable for use by businesses in order to increase revenues and profitability. Data harvesting and analysis has developed in to a large business, conducted by the organization itself or using specialist companies such as Experian, Equifax, Nielsen Claritas, and Global TGI. According to Kitchin and Dodge (2011) data analysis can be separated in to three themes. Firstly, data is used to profile customers by looking at what characteristics makes someone a potential customer, and secondly, to profile individual products by looking at things such as pricing, shelving and which location in the store is best suited for it. Thirdly, data is used to profile neighbourhoods and individual stores. By looking at these three aspects and the shifting interactions between them, businesses are using software to efficiently manage and plan retail, build relationships with customers, and geographically locate the business in the right neighbourhoods.

According to Crang and Graham (2007: 789) we now live in a world of sentient cities, in which "we not only think of cities, but cities think of us". The city environment should no longer be seen as a passive backcloth for social action, but instead as being saturated with anticipatory technologies, from Radio Frequency Identification (RFID) chips that give businesses the possibility to track and monitor a product through its entire life-spawn, to biometric sensors, such as finger prints, iris scans, DNA, face recognition and voice recognition that are used for bordering and surveillance. Instead of a unanimous big-brother, the sentient city is produced by a "messy infinity of little-brothers", of which some are commercial, some militarized, and some personal (ibid.). The migration of geodemographic classifications in to different forms of software sorting technologies is not only a theoretical issue, but even more importantly a policy one (Burrows 2008).

By accepting the premise that cities are becoming increasingly affected and run by digital technologies, social scientific research is seen to be facing a set of crucial methodological challenges. According to Savage and Burrows (2007, 2009) classical sociological research methods, and thereby the whole jurisdiction of the discipline, is moving towards a crisis. Between 1950 and 1990 the legitimacy of sociology was to a large extent based on the distinctive methodological tools that were invented in and used by the academia. Survey research and interviews were originally thought of as very innovative ways of doing research, as they allowed sociologists to claim clear access to social relations. As a result of the inundation of electronic data in our culture, the usefulness of these methods is increasingly unclear, and without up to date methods, the whole jurisdiction of sociology comes under question (ibid.).

Savage and Burrows (ibid.: 3-4) point out that in a world characterized as knowing capitalism where "complex circuits of information proliferate embedded in numerous kinds of digital technologies" (Thrift 2005), social knowledge is now routinely collected and analysed in ways which do not depend on the expertise of academic sociologists. As a result, academic sociologists are occupying far more marginal positions within the social research infrastructure than before. Sample surveys are not of much use for an organization that can routinely gather data as a by-product of institutional transactions. In order for sociology to regain its status, sociologists have to, according to Savage and Burrows (2007: 896), "cast their net wide", critically engage with the extensive data sources that now exist, and campaign for access to this data.

The analysis conducted in this article raises questions that directly touch upon the challenges pointed out by Savage and Burrows (ibid.). The information in Experian's data catalogue for Finland is at times difficult to grasp, and no clear explanation is given to how the classifications are built. Some important public data sources are 
mentioned, and one would guess that these sources are also used when building the geodemographic classifications. However, the fact that Experian is not fully open about its data sources and methods of constructing the classifications is a reason for sociological concern. If we accept the premise that the power to classify and label places and populations has shifted from nation states to commercial institutions, it is important that we understand how the final classifications are constructed. On the contrary to our common belief, data, and especially the ways which it is used, is not neutral (see for example Uprichard et al. 2009).

The analysis conducted in this article has also revealed major problems with the Mosaic Finland's mapping of the Helsinki metropolitan area. The premises for the methodological choices behind the classifications are derived from a cultural context of deep class divisions. Analysed from a historical, cultural and methodological perspective, the translation of these premises in to the context of a Nordic welfare state has resulted in a flawed picture of the capital region of Helsinki. Bearing in mind the growing global reach of technologies such as the Mosaic, it is important to note that different statistical techniques produce different results. The ability to critique these methodological choices is becoming an increasingly important feature of modern Social Sciences.

In February 2011, Experian released an iPhone application called Mosaic UK, which allows its users to identify the Mosaic category that matches the GPS location of the user's phone. The application can be used to search for the Mosaic category of any postcode, town or location. This is another step in a process in which sophisticated location data is becoming easily accessible for the public. The power of geodemographic classifications lie not in their accuracy, but in the fact they are seen as sufficient representations of social reality by governmental and commercial decision makers. Not least due to the increasing public availability of the data, we can see a potential future in which the labeling and classifying of areas contributes to accelerating processes of social polarization within our cities, where especially the affluent exercise great power in choosing where to live. Clearly sociologists need to rapidly combat the methodological issues that a thorough research on the influence and construction of commercial geodemographics would involve.

\section{Conclusion}

In this article I have examined the geodemographic classifications built of Helsinki. In order to gain a basic understanding of the city's social geography, I started by taking a look at its history and current social developments. Ever since its early days, the development of Helsinki has been strongly affected by governmental control. This history is evident in the city center even today, with the central district of Kruunuhaka entirely devoted to governmental and university buildings. Despite recent challenges, the city structure has been able to maintain balanced by international comparison. The emergence of new income inequalities, long-term unemployment and ethnic clustering are however causes for concern.

In the second part of the article I first looked at the key characteristics of the geodemographic systems in Finland, after which I analysed the maps of the Helsinki metropolitan area in detail. This analysis revealed the Mosaic Finland's tendency to systematically ignore areas at the both ends of the socio-economic scale. As a result of its inability to identify fine-grained social differentiation, the Mosaic Finland ends up portraying the Helsinki metropolitan area in a very problematic way to say the least. These issues that to a large extent stem from the methodological choices made during the initial building process, indicate a lack of understanding of the historical and cultural context of the region. The finding is very interesting considering the growing global reach of geodemographic systems, and it relates directly to the methodological questions raised in the last part of this article.

It is difficult to disagree with Savage and Burrows $(2007,2009)$ basic assertion that in our highly computerised and commercialised western societies, many sociologically significant tools for gathering knowledge of the social world are being developed outside of the academia. In these circumstances, it is undoubtedly so that one of the tasks of Social Science becomes to form an understanding of how these technologies are constructed and applied.

In order for this to be possible however, social scientists might need to be more active than so far in developing professional relationships also in the world outside of academia. In the case of this article, the data for the analysis was retrieved simply by contacting Experian, the producer of the Mosaic Finland classification system, and asking 
for it. In general, commercial actors might be more willing to share their data for research purposes than we might initially think. As more and more data now exists in the hands of private companies, questions around the public value of data are becoming increasingly important, and sharing it for the purposes of academic research is one way that companies can contribute to this debate.

Finally, the analysis conducted in this paper has once again highlighted the importance of understanding the cultural embeddedness of even those systems that at first sight may appear as purely technical. In a world that is increasingly run by software, here might be where the professional expertise of social scientists is needed the most.

\section{REFERENCES}

Allardt E, Alapuro R \& Alestalo M 1992. Suomalaisen sosiologian historiasta. In Alapuro R, Alestalo M \& Haavio-Mannila E (eds). Suomalaisen sosiologian historia, 13-25. WSOY, Porvoo (in Finnish).

Amin A \& Thrift N 2002. Cities: Reimagining the urban. Polity Press, Oxford.

Beer D \& Burrows R 2007. Sociology and, of and in Web 2.0: Some initial considerations. Sociological Research Online 12: 5, 17. http://dx.doi.org/10.5153/sro.1560.

Beer D 2009. Power through the algorithm? Participatory web cultures and the technological unconscious. New Media \& Society 11: 6, 985-1002. http://dx.doi.org/10.1177/1461444809336551.

Bourdieu P 1986. Distinction. Routledge, London.

Burrows R \& Gane N 2006. Geodemographics, software and class. Sociology 40: 5, 793-812. http:// dx.doi.org/10.1177/0038038506067507.

Burrows R 2008. Geodemographics and the construction of differentiated neighbourhoods. In Flint J \& Robinson D (eds). Community cohesion in crisis? New dimensions of diversity and difference, 219-237. Policy Press, Bristol.

Cantell T \& Jaakola A 2012. The publication Helsinki's present state and development 2013. Helsinki Quarterly 4, 55-58. <http://www.hel2.fi/tietokeskus/julkaisut/pdf/13_01_11_Quarterly. pdf> 22.1.2013.

Castells M \& Himanen P 2002. The information society and the welfare state: The Finnish model (No. 250). Oxford University Press on Demand, Oxford.

Chapain C, Stachowiak K \& Vaattovaara M 2010. Beyond cluster policy? Birmingham, Poznan and Helsinki. In Musterd S \& Murie A (eds). Making competitive cities, 263-285. John Wiley \& Sons, Chichester.
CIA 2012. The world factbook. <https://www.cia. gov/library/publications/the-world-factbook/ rankorder/2172rank.html> 14.8.2012.

Crang M \& Graham S 2007. Sentient cities: Ambient intelligence and the politics of urban space. Information, Communication \& Society 11: 6, 789-817. http://dx.doi.org/10.1080/13691180701750991.

Experian 2010. Mosaic Finland. Group and type descriptions (English). Experian Ltd., Nottingham.

Experian 2011. Finland data catalogue. Experian Ltd., Nottingham.

Experian Marketing Services 2011. MOSAIC Finland. Experian Ltd., Nottingham.

Florida RL 2002. The rise of the creative class: And how it's transforming work, leisure, community and everyday life. The Perseus Books Group, NewYork.

Florida RL 2012. The rise of the creative class: Revisited. Basic Books (AZ), New York.

Gillespie T 2013. The relevance of algorithms. In Gillespie T, Boczkowski P \& Foot K (eds). Media technologies: Essays on communication, materiality, and society. MIT Press, Cambridge.

Graham S 2005. Software-sorted geographies. Progress in Human Geography 29: 5, 562-580. http:// dx.doi.org/10.1191/0309132505ph568oa.

Harris R, Sleight P \& Webber R 2005. Geodemographics, GIS and neighbourhood targeting. Wiley, Chichester.

Helsingin kaupungin tietokeskus 2010. Kaupungin vuokra-asunnot ja asukkaat 2010. <http://www. hel.fi/hel2/tietokeskus/julkaisut/pdf/11_06_10_ tilasto_16_vihavainen.pdf> 13.8.2014 (in Finnish). Helsingin kaupungin tietokeskus.

Herkman J 2001. Audiovisuaalinen mediakulttuuri. Vastapaino, Tampere (in Finnish).

Kepsu K \& Vaattovaara M 2008. Creative knowledge in the Helsinki Metropolitan Area. Understanding the attractiveness of the metropolitan region for creative knowledge workers. ACRE report 5.5. AMIDSt, University of Amsterdam.

Kitchin R \& Dodge M 2011. Code/Space: Software and everyday life. MIT Press, Cambridge.

Kortteinen M \& Vaattovaara M 2011. Social differentiation within the Helsinki region: New stage in development. Verbal presentation for the city administration. 20.5.2011.

Mäkelä K 1999. Valtio, väkijuomat ja kulttuuri. Kirjoituksia Suomesta ja sosiologiasta. Gaudeamus, Tampere (in Finnish).

Laakso S \& Loikkanen HA 2004. Kaupunkitalous. Gaudeamus, Helsinki (in Finnish).

Laakso S \& Vuori P 2013. Population development in Helsinki and the Helsinki Region - Realised population growth and projections until 2050. Helsinki Quarterly 4, 6-15. <http://www.hel2.fi/tietokeskus/julkaisut/pdf/13_01_11_Quarterly.pdf> 22.1.2013. 
Parker S 2011. Cities, politics and power: Critical introductions to urbanism and the city. Routledge, Oxon.

Parker S, Uprichard E \& Burrows R 2007. Class places and place classes: Geodemographics and the spatialization of class. Information, communication and society 11: 6, 901-921. http://dx.doi. org/10.1080/13691180701751122.

Ritakallio V 2010. The state of poverty in Finland 2010. A presentation at Sosiaalipolitiikan päivät in Helsinki 21.-22.10.2010.

Salorinne M 2014. Helsingin työttömyys alueittain vuoden 2013 lopussa. <http://www.hel.fi/hel2/ tietokeskus/julkaisut/pdf/14_07_08_Tilasto_21_ Salorinne.pdf> 12.8.2014 (in Finnish). Helsingin kaupungin tietokeskus.

Savage M \& Burrows R 2007. The coming crisis of empirical sociology. Sociology 41: 5, 885-889. http://dx.doi.org/10.1177/0038038507080443.

Savage M \& Burrows R 2009. Some further reflections on the coming crisis of empirical sociology. Sociology 43: 4, 762-772. http://dx.doi.org/10.1177/0038038509105420.

Thrift N 2005. Knowing capitalism. Sage, London.

Thrift N \& French S 2002. The automatic production of space. Transactions of the Institute of British Geographers 27: 4, 309-350. http://dx.doi.org/10.1111/1475-5661.00057.

Uprichard E, Burrows R \& Parker S 2009. 'Geodemographic code and the production of space'. Environment and Planning $A$ 41: 12, 2823-2835. http://dx.doi.org/10.1068/a41116.
Uusitalo H 1997. Four years of recession: What happened to income distribution? In Heikkilä $M$ \& Uusitalo H (eds). The cost of cuts, 101-118. National Research and Development Centre for Welfare and Health, Helsinki.

Vaattovaara M 1998. Residential differentiation within the metropolitan area of Helsinki, Finland - Environment and spatiality. Helsinki Urban Facts, Helsinki.

Vaattovaara M \& Kortteinen M 2003. Beyond polarization versus professionalization? A case study of the Helsinki region, Finland. Urban Studies 40: 11, 2127-2145. http://dx.doi.org/10.1080/00420 98032000123213.

Vaattovaara M, Schulman H \& Kortteinen M 2011. A Nordic welfare model at a turning point? Social housing and segregation in Finland. In Driant J-C \& Houard N (eds). Social housing across Europe, 49-70. La documentation Francaise, Paris.

Vilkama K 2006. Asuntopolitiikka ja vieraskielisen väestön alueellinen keskittyminen Helsingissä vuosina 1992-2005. Thesis (MSc). University of Helsinki (in Finnish).

Vilkama K 2012. Socio-economic and ethnic differentiation of neighbourhoods in Helsinki, Helsinki Quarterly 4, 24-31. <http://www. hel2.fi/tietokeskus/julkaisut/pdf/13_01_11_ Quarterly.pdf> 22.1.2013.

Waris H 1932. Työläisyhteiskunnan syntyminen Helsingin Pitkänsillan pohjoispuolelle: I. Thesis (PhD). Suomalaisen Kirjallisuuden Seuran Kirjapaino Oy, Helsinki (in Finnish). 